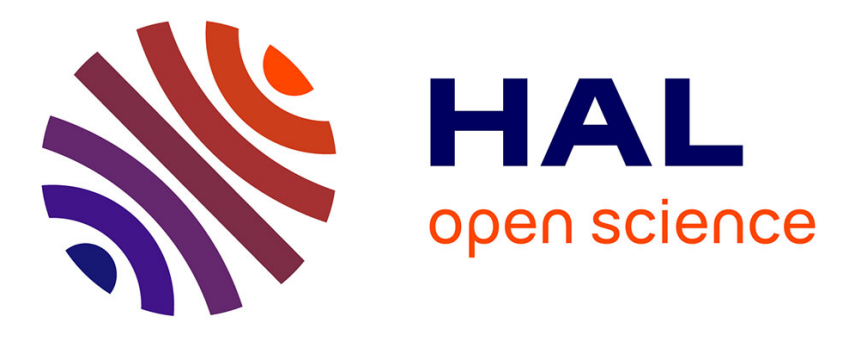

\title{
Reputational spillovers: evidence from french architecture
}

Amélie Boutinot, Shahzad Ansari, Mustapha Belkhouja, Vincent Mangematin

\section{To cite this version:}

Amélie Boutinot, Shahzad Ansari, Mustapha Belkhouja, Vincent Mangematin. Reputational spillovers: evidence from french architecture. Strategic Organization, 2015, pp.Forthcoming. $10.1177 / 1476127015597581$. hal-01183392

\section{HAL Id: hal-01183392 \\ http://hal.grenoble-em.com/hal-01183392}

Submitted on 7 Aug 2015

HAL is a multi-disciplinary open access archive for the deposit and dissemination of scientific research documents, whether they are published or not. The documents may come from teaching and research institutions in France or abroad, or from public or private research centers.
L'archive ouverte pluridisciplinaire HAL, est destinée au dépôt et à la diffusion de documents scientifiques de niveau recherche, publiés ou non, émanant des établissements d'enseignement et de recherche français ou étrangers, des laboratoires publics ou privés. 


\author{
Amélie BOUTINOT ${ }^{1}$ \\ Institut Supérieur de Gestion, 147, avenue Victor Hugo, \\ 75116 Paris, France. \\ Phone: +33 681112368 , \\ Email: amelieboutinot@gmail.com
}

Shahzad (Shaz) ANSARI

Judge Business School, University of Cambridge, Cambridge, CB2 1AG, United Kingdom. Phone: +44 1223768 128, Fax: +44 1223339701 ,

Email: s.ansari@jbs.cam.ac.uk

\title{
Mustapha BELKHOUJA
}

Grenoble Ecole de Management, 12, rue Pierre Sémard, 38000 Grenoble, France.

Phone: +33 4568066 68, Email:

Mustapha.belkhouja@grenoble-em.com

\section{Vincent MANGEMATIN}

Grenoble Ecole de Management, 12, rue Pierre Sémard, 38000 Grenoble, France. Phone: +334767060 58,

Email: Vincent.mangematin@grenoble-em.com

\footnotetext{
${ }^{1}$ Corresponding author.
} 


\title{
REPUTATIONAL SPILLOVERS: EVIDENCE FROM FRENCH ARCHITECTURE
}

\begin{abstract}
While the notion of reputation has attracted much scholarly interest, few studies have addressed the strategic issue of reputational multiplicity and managing the interactions among different types of reputations. We suggest that an organization can have several stakeholderspecific reputations - peer, market, and expert - and that reputational spillover effects (the continued influence of one reputation on another) matter at the organizational level. We test reputational spillovers on 42 French architecture companies over a period of 30 years. Our results show that over time, the three reputations interact with each other, generating positive spillovers, with the exception of market and expert reputations. We contribute by explaining how interconnected organizational reputations among different stakeholders can interact over time, how companies can strategically manage reputational spillovers, and how such spillovers influence organizations in creative and professional industries.
\end{abstract}

Keywords: Reputation; Spillover effects; Selection-system theory; Creative industries; Architecture 


\section{INTRODUCTION}

Scholarly work on reputation has significantly expanded our understanding of reputation as a strategic asset to enable higher performance, provide competitive advantage, and allow stakeholders to make inferences about an organization, especially in the absence of more specific information about its characteristics and behaviors (Benjamin and Podolny, 1999; Podolny, 1993). While recent studies have examined how reputation judgments and assessments are formed (e.g., Bitektine, 2010; Love and Kraatz, 2009; Mishina, Block, and Mannor, 2012; Tost, 2011), we still need a better understanding of the multi-faceted nature of reputation, how an organization may have different types of reputation and how these different types of reputation may interact over time.

Mishina and colleagues (2012: 460) define reputation as "the collective stakeholder groupspecific assessment regarding an organization's capability to create value based on its characteristics and qualities." Reputation is often conceptualized as a unitary construct, where an organization has one overall reputation (Fombrun, 1996; Fombrun, Gardberg, and Sever, 2000; Fombrun and Shanley, 1990). It is also considered to be multidimensional - i.e., composed of and affected by various characteristics and actions of the firm, such as financial performance and socially responsible behavior (Fombrun et al., 2000; Fombrun and Shanley, 1990; McGuire, Sundgren, and Schneeweis, 1988). However, reputation also may vary in terms of how different stakeholder groups perceive and value it (Carter and Deephouse, 1999; Dollinger, Golden, and Saxton, 1997; Mishina et al., 2012). For example, Walmart's reputation with customers and investors has historically been starkly different from its reputation with employees and local communities (Carter and Deephouse, 1999). While a company can have multiple stakeholder-specific reputations, previous studies have fallen short on explaining how such multiple reputations can co-exist and influence each other over 
time. To what extent do these reputations influence each other? To what extent are they complementary or conflicting?

We build on previous arguments about multiple reputations (Carter and Deephouse, 1999; Dollinger et al., 1997; Mishina et al., 2012) to study reputational spillovers. In line with previous studies of spillovers such as those of knowledge (e.g., Azoulay, Zivin, and Wang, 2010; Zucker, Darby, and Brewer, 1998), we define spillovers as positive or negative externalities of resources, activities, or processes that affect parties or entities not directly involved. Considering that reputation is a key intangible resource, reputation spillovers are positive or negative externalities arising from one stakeholder-specific reputation influencing another stakeholder-specific reputation. Studying the impact of reputational spillovers can provide an enhanced understanding of how companies manage various forms of reputations, deal with a plurality of stakeholders to minimize reputational gaps (Davies, Chun, and Kamins, 2010) over time, and navigate reputational complexity and dynamism (Barnett and Pollock, 2012; Lange, Lee, and Dai, 2011).

We develop and test a theoretical model of the connections among different kinds of reputations. To do so, we complement reputation studies with selection-system studies (e.g., Wijnberg, 2004; Wijnberg and Gemser, 2000), which analyze organizational reputation from the perspective of stakeholders' evaluations. Specifically, even if these studies are more concerned with competitive processes around an evaluation process, they reveal that an organization can have at least three stakeholder-related reputations; peer (reputation with other producers in the industry), market (with potential customers), and expert (with critics or social judgment providers - neither producers nor consumers). This is particularly relevant to creative industries such as art, movie, music, and architecture (Alvarez, Mazza, Pedersen 
Strandgaard, and Svejenova, 2005; Svejenova, 2005). Drawing on these insights, we empirically investigate the spillovers between peer, market, and expert reputations of companies in the context of contemporary French architecture. To test these spillovers longitudinally, we elaborate a simultaneous-equations econometric model of reputation, based on panel-data observations.

We found that over time, the three reputations interact with each other, generating positive spillovers, with the exception of market and expert reputations. Specifically, peer reputation is pivotal, spilling over on both market and expert reputations. Experts select among those architects that enjoy peer recognition, represent avant-gardism, and make their work and their name known more widely. Market reputation, which is based on commercial considerations, generates negative spillovers on expert reputation, as experts tend to value distinctiveness and creativity more than they value commercial success.

Based on these findings, we extend research on organizational reputations by providing several insights into reputational complexity and dynamism over time, answering recent calls for further research (Barnett and Pollock, 2012; Lange et al., 2011). First, while previous studies have addressed the co-existence of different reputations with different stakeholders (Carter and Deephouse, 1999; Dollinger et al., 1997; Mishina et al., 2012), we discuss the interactions among the different stakeholder-specific reputations and the conditions under which they can happen. Second, we complement studies of reputation multiplicity (e.g., Dollinger et al., 1997; Lange et al., 2011; Mishina et al., 2012) by suggesting how companies can strategically manage such reputational spillovers by presenting a two-way reinforcing approach, at the organizational and institutional levels. Third, we provide insights into how reputational spillovers influence organizations in creative and professional industries (Cooper, 
Hinings, Greenwood, and Brown, 1996; Jones and Livne-Tarandach, 2008), and explain how reputational spillovers may have different dynamics, depending on the nature of the industry.

\section{THEORETICAL BACKGROUND}

\section{Perspectives on reputation}

Organizational reputation is defined as the "stakeholder-specific assessment regarding an organization's capability to create value" (Mishina et al., 2012: 460). As such, reputation can be conferred by several stakeholder profiles, such as analysts (Zuckerman, 1999) or critics (Rao, Monin, and Durand, 2003). Also, depending on the profile of the stakeholder group, reputation may significantly vary (Carter and Deephouse, 1999; Dollinger et al., 1997). This is because each stakeholder group has its own way and criteria of assessing and conveying information about an organization, so that one type of reputation corresponds to a particular stakeholder. Indeed, recent work has called for more attention not only to the multidimensionality but also to the multiplicity of reputational forms (Fombrun and Van Riel, 2003; Lange et al., 2011; Rindova, William, and Petkova, 2005; Mishina et al., 2012). Carter and Deephouse (1999) explained how Wal-Mart is known to be tough among suppliers and to be efficient and capable among customers and investors. Lange and colleagues (2011: 155) distinguished among "being known (generalized awareness or visibility of the firm; prominence of the firm in the collective perception), being known for something (perceived predictability of organizational outcomes and behavior relevant to specific stakeholder interests), and generalized favorability (perceptions or judgments of the overall organization as good, attractive, and appropriate)." Similarly, Mishina and colleagues (2012) suggested that stakeholders make two primary types of reputational assessment when evaluating a target organization, drawing distinctions between the favorability of an organization's capabilities (capability reputation) and that of its character (character reputation). Thus, rather than 
considering the multiple (positive or negative) dimensions of a unitary overall reputation, these studies recognize the existence of multiple forms of reputation, depending on the particular stakeholders involved.

While these studies have addressed the multiplicity of reputational forms, we argue that the dynamics of such multiplicity are still relatively poorly understood. In particular, we know little about the possible interrelationships among the different types of reputation in pluralistic environments. For instance, Carter and Deephouse's study of Wal-Mart (1999) gives no clue about if and how a change in Wal-Mart's tough reputation among its suppliers might affect its positive reputation among customers and investors. Are there spillover effects among the various types of reputation at the organizational level? Do the various types of reputation undermine or nourish each other over time?

To refine the knowledge of stakeholder-specific reputations, we draw on selection-system studies as a theoretical instrument to complement reputation studies.

\section{Perspectives on selection system}

Selection-system studies deal with how selectors assess organizations and choose particular ones - the selected - that stand out over time (i.e., increase or maintain their reputations). Even if the main focus of this theoretical approach is not on reputations per se, it provides insights into how organizations can have multiple reputations by examining who shapes value, and how, during competitive processes in pluralistic environments (Gemser, Leenders, and Wijnberg, 2008; Mol and Wijnberg, 2011; Wijnberg and Gemser, 2000).

While the literature on reputation acknowledges that each stakeholder confers a certain type of reputation (Carter and Deephouse, 1999; Dollinger et al., 1997; Mishina et al., 2012), the 
selection-system approach highlights three clear-cut profiles of selectors among whom to develop a reputation; peer (when selectors and selected belong to the same group or industry, and when selectors are other industry producers, such as in academia); market (when selectors are customers, while selected are industry producers, such as in everyday products in supermarkets); and expert (neither producers nor consumers - when selectors have acquired expertise in a given domain, such as professional critics) (Wijnberg and Gemser, 2000). These stakeholders may use different and distinct signals of value to assess the quality of an organization. We therefore build on the idea that one kind of stakeholder confers one kind of reputation; peers confer peer reputation, clients or consumers confer market reputation, and critics confer expert reputation.

Peer reputation corresponds to the specific assessment by organizations of the same domain (i.e., fellow producers) regarding an organization's capability to create value for their domain of activity. For this audience, the term value refers to improvements of ideas, conceptual approaches, and materials within their domain of activity, pushing forward its boundaries. This perception reflects a sign of excellence in a particular domain. For instance, Ebbers and Wijnberg's study of nascent ventures in the movie industry suggests that a movie director's peer reputation for the quality and diversity of movie productions is attributed through fellow producers or directors (2011). This means that peers are aware of each other's works (Wijnberg and Gemser, 2000) and of belonging to the same social group, which confers a degree of coherence in the roles and goals.

Market reputation corresponds to the specific assessment by clients regarding an organization's capability to create value, i.e., to satisfy clients' expectations. In this stakeholder group, the term value reflects the satisfaction of people or companies buying the 
work. For instance, in the movie industry, box-office success in terms of ticket sales of a dedicated movie can represent value for investors giving money to a particular movie production firm (Ebbers and Wijnberg, 2011). As such, market reputation is based on general trustworthiness: Organizations have to show their ability to deliver on clients' expectations (Becker, 1997; Mayer, Davis, and Schoorman, 1995).

Expert reputation refers to the specific assessment by cultural critics regarding an organization's capability to create value for society in general. Experts are neither peers nor clients, but have expertise in the field, and a distinctive ability to disseminate knowledge and valued opinions (Mol and Wijnberg, 2011). Such knowledge often originates from their training and social background, often complemented by journalism. Thus, experts usually take the form of journalists and critics. Their main activities are to identify organizations and to use classification systems to assess and position them in relation both to other organizations and in a historical sequence (Wijnberg and Gemser, 2000). They promote in broader society the works of certain organizations that they see as impactful. This is done mostly through articles in the mass media, events, or conversations about culture and intellectual society. For example, in the movie industry, because such organizations provide works both that are relevant to this domain of activity and that can make society think and react, expert reputation of movie directors is based on film critics' reviews in mass newspapers that inform and guide the general public (Ebbers and Wijnberg, 2011).

As such, we see that the three types of reputation are based on different signals of value. Understanding the complex relationship among them can provide important insights. Moreover, selection-system theory has often been applied in cultural and creative sectors. Creative industries supply "goods and services that we broadly associate with cultural, artistic 
or simply entertainment value" (Caves, 2000: 1). In industries such as visual arts, performing arts, design, and architecture (Alvarez et al., 2005), organizations are engaged in conceiving, developing, and distributing artifacts and experiences with aesthetic properties and symbolic functions, where novelty and differentiation are crucial in shaping recognition and value (Jones, Anand, and Alvarez, 2005; Svejenova, Planellas, and Vives, 2010). Because creative organizations are known to produce singular and unique artifacts, marked by their signature and authorship, reputation issues target not only their products but also the organizations themselves. Indeed, the novelty and uniqueness of an artifact enhances the organization's reputation, which is often a key to success. These industries therefore present sites of potential reputational spillover on which we build to develop our core arguments. For instance, in visual arts, organizations first need to acquire reputation among their peers in order to be able to achieve broad recognition among the general public; this takes time, sometimes even several decades (Lang and Lang, 1988). In such cases, peers can be seen as parties who need to be satisfied so that creative organizations' contributions can continue to be more widely recognized.

Finally, in order to inform the debate on stakeholder-specific reputations, we draw in particular on Ebbers and Wijnberg's study of reputation in the Dutch movie industry (2011). Indeed, selectors can be considered as stakeholders in the sense that they both evaluate and promote organizations in a given industry - considered as a competitive arena. Moreover, like selectors, each stakeholder group has its own specific evaluation process. While the notions of stakeholders and selectors may not be completely synonymous, our focus on reputational issues enables us to connect them in developing our theory. 
This theoretical linkage reveals that multiple reputations may go in different directions. Our goal is therefore to untangle the complexity of how various stakeholder-specific reputations emerge and possibly co-exist over time. To do this, it is necessary to shed further light on the interactions between various stakeholder-related reputations. Using selection-system and creative-industries studies as theoretical levers to extend the reputation debate, we study the interactions among the various forms of reputation.

\section{Reputational spillovers - hypotheses development}

A key motivation of our hypotheses development stems from the notion of reputation commons - one company's vilified reputation can damage other companies' reputation in the industry (King, Lenox, and Barnett, 2002), and vice versa. Applied to the organizational level, a vilified/glorified reputation with one stakeholder may negatively/positively influence reputations among other stakeholders.

\section{Peers and market reputational spillovers}

Interactions between peers and clients may originate from several sources, such as critics' writings, television shows, and (more directly) artwork commissions - when a client commissions a particular work or project. Several scholars have noted that creative organizations positively influence the market's judgments about a peer. In their study of awards in the film industry (2008), Gemser and colleagues showed that peers and endconsumers nourish each other's perceptions. The reputation that organizations attribute to their peers is often also valued by clients. Likewise, in visual arts, Galenson (2005) argued that the best advice for a dealer or collector about which artwork to buy comes from painters themselves, suggesting that the more one is reputed among peers, the more reputed one will be among clients. Drawing on these studies, we can infer that peers act as prescribers for the 
market. Through their artistic qualifications, they are able to guide clients who may not know which organizations to select for their projects, or whose artworks to exhibit or buy. We infer that such guidance, albeit indirect, can influence the market's perception of an organization. We therefore hypothesize:

(H1a): Peer reputation positively impacts market reputation.

Market reputation may influence peer reputation. Some studies view the symbolic and economic sides of creative sectors as oppositional (Eikhof and Haunschild, 2006; Heinich, 1991; Lampel, 2000). Creative organizations may deliberately negate the economic side of art, especially when they have to produce goods to meet a client's commercial demands. As evident in the history of architecture itself (Thornton, Jones and Kury, 2005), this apparent conflict between aesthetics and efficiency raises the issue of a potential lack of freedom and avant-gardism, since the client may not understand a highly aesthetic avant-garde work and may therefore prefer less novelty in creative works. As Caves (2000) argued in his study of contracts between arts and commerce, if the dealer hires the actor to paint what the former thinks will sell, creative autonomy clearly seems diminished. Even if this view may have declined lately, and the absence of economic and commercial incentives may be counterproductive, the idea is still present in actors' minds and in perceptions of what art is fundamentally about. For instance, architecture companies that meet a client's needs without suggesting innovative designs or a new concept for the building may not be held in high esteem by other architects. The project may be assessed as yet another building driven by commercial goals, and be less likely to be remembered by the profession. In addition, creative organizations may discount the market philosophy, in that there may be some strategic or political moves behind the purchase of creative goods. For instance, presidents and city mayors may base their decisions to commission or buy a building more on the desire to 
promote their country, city, or own name than on the merits of the building or that of the architecture company. We thus hypothesize:

(H1b): Market reputation negatively impacts peer reputation.

\section{Market and expert reputational spillovers}

Concerning the potential spillover effects between market and expert reputations, some studies noted that the two can complement each other over time (Bowness, 1990; Lang and Lang, 1988; Wijnberg and Gemser, 2000). Such interactions are possible, sometimes indirectly, when clients read experts' written commentaries, or signal their choice about who to hire for a project or a piece of artwork. They can also directly meet at social events, such as gala dinners and awards ceremonies, to which both groups may be regularly invited.

In terms of how the market may influence experts, Bowness (1990) - in his study of modern art - argued that critics cannot be aware of organizations that have never sold anything, and that have never received any financial support from clients. Reputation with cultural elites seems to be based on concrete evidence of ability, and reputation previously established with clients. He therefore suggested that critics are similar to art dealers and buyers in this respect. Similarly, Moulin (1967), in her studies of French painters, highlighted that experts become reflective critics when explaining and promoting clients' decisions to invest in works of art, and leverage what the market values in order to identify and promote organizations. Drawing on these ideas, we infer that such interactions with the market may influence the way in which experts develop their own views about organizations. We therefore hypothesize:

(H2a): Market reputation positively impacts expert reputation. 
Referring to how the expert stakeholder influences the market, Becker (1982) highlighted that cultural intermediaries or critics guide potential clients toward organizations through their commentaries and writings. In their study of Impressionism, Wijnberg and Gemser (2000) explained the success of Impressionists through the rise of experts who both assisted art dealers in choosing whose work to invest in and convinced buyers about the value of art. Moreover, Lang and Lang demonstrated that critics and their promotion of organizations attract not only those seeking to invest in art but also those seeking to increase their image as collectors (1988). We therefore hypothesize:

(H2b): Expert reputation positively impacts market reputation.

\section{Peer and expert reputational spillovers}

Experts interpret, popularize, and promote artistic works. Interactions between peers and experts are based on experts' articles, meetings, and social events dedicated to art, awards ceremonies, festivals (national or international), and periodic events (such as the Venice Biennale), where producers and experts meet.

Previous research has argued that having a high reputation with peers generates positive spillovers with experts, who aim to discover innovators and the avant-garde. Bowness's (1990) model suggests that being reputed among peers improves one's chances of becoming highly recognized among critics, as peers' validation echoes the producers' professional ability to innovate. Likewise, Wijnberg and Gemser, in their study of Impressionism, show that there is a "symbiotic relationship" between organizations that pursue distinctiveness and experts who can help establish its value (2000: 324). Finally, Galenson (2005) suggested that the opinions of peers can positively affect those of experts. Organizations that are highly reputed among peers are more likely to be promoted and remembered by the wider public 
than those less reputed among peers; they therefore value experts' work. Indeed, experts themselves have their own reputation to take care of, and promoting a well-known organization may help their own reputation to increase. The aura of the producer may thus benefit the promoter (Moulin, 1967). Such interactions can influence the way in which experts judge producers. We therefore hypothesize:

(H3a): Peer reputation positively impacts expert reputation.

On the contrary, several studies have highlighted experts' negative influence over how producers are perceived. Several studies dedicated to the cultural and creative sectors note that being too visible outside their close circle of peers can damage organizations' ability to innovate - as an attestation of their conformance to norms and a lack of creativity (Heinich, 1991, 2004; White and White, 1965). Indeed, in order to be known by experts, organizations need to be clearly identifiable, and to be able to reproduce what they have done before to become trustworthy and reliable. However, this may hurt creativity and the reputation among peers. As a consequence, being highly connected to and promoted by experts may negatively influence organizations' ability to innovate, and damage peer perception of their talent over time. Also, an expert's positive perception of organizations can help those who already enjoy peer recognition to expand their renown over time, easing their way to posterity (i.e., going beyond their lifetimes) - for instance, by cataloging their works (Lang and Lang, 1988). Despite this potential long-term gain brought about by expert reputation, high reputation outside their circles of peers (i.e., among experts) can damage peers' perceptions of producers in the short term. We therefore hypothesize:

(H3b): Expert reputation negatively impacts peer reputation. 
We now present our empirical testing of the spillover effects over time among the various types of reputation.

\section{METHOD}

\section{Context and sample}

Architecture is the art of creating and constructing spaces or buildings, be they public (housing, religious and state-owned buildings, equipment such as bridges or aqueducts, cities, and neighborhoods) or private (headquarters, offices, production sites, etc.). Architecture is not simply about the architecture companies' ability to create work that is functional, beautiful (Champy, 2001), and avant-garde (Guillen, 1997); it serves a symbolic and commercial function (Jones et al., 2005; Jones, Maoret, Massa, and Svejenova, 2011). Therefore, architecture companies manage to combine art, market, and recognition. Indeed, architecture corresponds to art on demand, which happens when a commissioner requests an artwork or a creative solution to meet particular needs. In the same vein, architecture companies submit an architectural proposal to create or renovate a building for a public or private client. This shows that recognition is a prerequisite to receiving requests for specific works. In line with our theoretical approach, we selected architecture as an empirical field of study. It is an example of pluralistic and creative industry (Alvarez et al., 2005), where reputational issues are a major concern for architecture companies, in addition to the reputation of their artifacts. These companies may face several and potentially conflicting reputations.

Architecture companies need to be known to carry out their work, and often aspire to express their own vision of space within society. Differentiation and avant-gardism are key attributes for architects, and aesthetic properties and symbolic functions - in addition to functionality - 
are highly valued. They also have to deal with experts who may value their work and ideas by writing and talking about them.

We restricted our study population to French architecture, in order to avoid cross-cultural issues arising from audience heterogeneity - differences in the cultural knowledge and preferences - (Kim and Jensen, 2014) and to provide a coherent context for selection systems. Architecture is constrained by nationally distinct mechanisms (Winch and Schneider, 1993), creating a national, cultural, and regulatory framework for our study. Nevertheless, international (or at least European) rules exist to regulate the activity at a broader level. The integration of French architectural practices into European and international standards suggests that our study is connected to the global architectural industry.

In order to test our hypotheses and take account of the specific conditions of spillovers in answering our research question, we created a sample of contemporary French architecture companies using the following criteria. First, we considered companies that had been active in the field for more than 30 years between the late 1970s and 2008, in order to trace their activities over time. We selected the end of the 1970s as the starting point because this period reflected the beginning of new trends in the profession, new reputational issues, and a new organization of the selection system. Second, we focused on companies with names associated with those of the founder architects, in order to track authorship - a crucial reputational element in these domains. Third, we kept in our sample only those for which relevant information about reputation was available over a 30 -year period.

This list comprised 42 contemporary French architecture companies. This sample represents a coherent set of organizations with various reputations, and potential spillovers among these 
reputations over time. Building a sample from scratch could represent selection bias, as we purposefully chose companies that had been active for over 30 years. However, our aim was to examine not organizational survival or performance per se, but rather reputational spillovers. In this sense, our sample is appropriate for addressing our research questions.

\section{Data collection}

We tracked the trajectory of each of our sample organizations from 1978 to 2008. Year by year, we traced their activity and how peers, clients, and experts perceived them, through the sample companies' websites. We complemented this data collection with information from books, general websites about architecture, the French architectural press, and the mass media. We also collected data concerning the founder architects' lives through their CVs, and data about the industry, such as the growth in the number of French architects and the budget allocated to culture (including architecture) by the French Ministry of Culture, an important player in the field of architecture since the 1970s. This gave rise to a database encompassing 31 years of each company's trajectory and history, including its engagement with various stakeholders.

\section{Measures}

Our model tested the connections over time among peer, market, and expert reputations. Our choice of indicators was not driven by the conventional metrics of reputation, such as rankings, awards, and judgments (Delmestri, Montanari, and Usai, 2005; Pfarrer, Pollock, and Rindova, 2010; Rao, 1994). Indeed, contrary to many other domains, architecture has no rankings of companies or buildings, and awards are given by multidisciplinary committees (and thus cannot be attributed to one stakeholder or another). 
To operationalize the three types of reputation in architecture, we drew on previous studies that have considered media coverage as providing a window through which to study the reputation-building process (Pfarrer et al., 2010; Rindova, Petkova, and Kotha, 2007). Indeed, journalists inform their stakeholders about the legitimacy and quality of firms and their leaders (Pollock and Rindova, 2003). Thus, media dedicated to a particular stakeholder (such as professional architectural magazines) can reflect what is seen as legitimate - and so valued - in that stakeholder's eyes. Our archival study made us aware that these articles might not cover all the relevant information. We thus drew on press coverage to elaborate the variables that would enable us to understand how the different kinds of reputation might interact over time. We used a five-year window immediately preceding each year to measure each kind of reputation that may be influenced by other reputations. In order to construct reputation measures - and not only ones related to visibility - for every stakeholder group, we made sure that our sources covered the companies' capability to create value, as we explain below.

\section{Peer reputation}

Involving one architecture company's assessment of another's capability to create value for architecture, this reputation was measured by the number of articles dedicated to each company's outputs in the five most-read French architecture journals during the period $t-1$ through $\mathrm{t}-5$ years. We selected the magazines AMC Le Moniteur, Technique et Architecture, L'Architecture d'Aujourd'hui, and Architecture Créé as representing the main informationtransmission vehicles for this stakeholder (based on their 2008 circulation figures and their all having been created before 1978). We focused our data collection only on newspapers, omitting the Internet, since our period of study started before the existence and public use of electronic media. The journals included are run by architects who have often become regular journalists (such as Jacques-Franck Degioanni, a regular contributor to Le Moniteur, a key 
weekly journal in architecture), and can thus be considered as examples of peers judging peers on quality and avant-gardism for architecture. In line with the selection-system approach, considering that experts cannot be producers themselves, architecture magazines in fact operationalize peer reputation better than expert reputation.

Two arguments support our choice of journals. First, given that the journals concerned are dedicated to architecture, they are likely to closely reflect the preferences of the architects at whom they are targeted. Second, since the content of architecture magazines relates to highquality projects, focusing on relevant and innovative projects from other architects, these contributions also serve to recognize the merit of the selected companies' outputs. For instance, an article dedicated to an architecture company's work in 2003 is entitled: "Innovative concrete: Time for architectural audacity." Hence, none of the articles identified could be considered as reporting on the relevant company or artifact in an unfavorable way.

\section{Market reputation}

This is based on the assessment by its clients of an architecture company's capability to create value for their city (in the case of state authorities) or business (in the case of private companies). Here, our stance differs slightly from the traditional selection-system approach. We view clients only as public authorities or private companies that purchase creative goods for professional reasons (e.g., to develop their activity or to create a new cultural space for their city). Following this approach, we measured market reputation by the average number of tender invitations that each architecture company received during the period $t-1$ through $t-5$ years. Architecture companies are invited to contests because the client has already heard their names from previous works, and because they are judged to be more relevant to the client's project than are their peers. State authorities or public bodies finance more than 70 per cent of construction sites (for building or refurbishing schools, museums, and public spaces in 
general), while other architects' clients are private companies or individuals, commissioning the construction or refurbishment of offices, houses, production facilities, etc.

\section{Expert reputation}

This relates to the critics' assessment of an architecture company's capability to create value for society. In order to differentiate clearly between expert and market reputation, we again take a slightly different stance from the traditional selection-system approach to experts. We consider that experts talk to society in general, i.e., to individuals who do not necessarily buy creative goods but are in some way connected to them (as the users or viewers of a building, for instance). These changes provide a more faithful representation of architecture, in which customers may be both purchasers and non-buying users. We measured expert reputation by the number of articles (in terms of columns) dedicated to each architecture company of our sample in the four most-read mass-media publications, in the period $t-1$ through $t-5$ years. In line with their circulation figures and their year of creation (prior to 1970), these publications were Le Monde, Les Echos, Le Point, and Libération. Again, we omitted the Internet. This branch of lifestyle journalism has not evolved greatly since the late 1940s both in France and worldwide, with similar articles appearing in publications such as The New Yorker and The New York Times in the United States. These publications may prefer to dedicate their time and column inches to controversial and interesting topics or people rather than writing negatively about architecture.

\section{Control variables}

Because the profession has grown since the 1970s, we argue that the increase in the total number of architects in France might affect peer reputation. To operationalize this, we reported the total numbers of architects working in France each year. Moreover, we controlled 
market reputation with the annual budget of the French Ministry for Culture between 1978 and 2008, on which architecture depends (the clients of the architects under study mostly being public authorities). We reported the amount in millions of constant euros on a yearly basis. While the data available does not show clearly the budgetary split among the various cultural categories over time, it can nevertheless improve the analysis by taking into account the variation in the total money spent. Finally, we controlled expert reputation with exhibitions, which we measured by counting the number of national and international exhibitions to which our sample of architecture companies contributed between 1978 and 2008, in the period t-1 to t-5 years. Exhibitions could have an impact on expert reputation because they provide a visible explanation of companies' works and views on architecture. They may therefore influence opinions, especially those of experts, who may value signs of accomplishment at the societal level, or even participate in organizing such events.

We generally controlled our model with several transversal variables. First, in order to control for the mixed-profile perspective of value creation among the three stakeholders, we included the awards won by the sample architecture companies in our model. Architecture awards are given to architects for artworks that are considered superior to other buildings, by a mixedprofile jury (architects, clients, critics, residents, etc.). We listed and counted all the awards that our sample architecture companies received, both national (such as the Grand Prix National d'Architecture) and international (such as the Pritzker Prize), in the period t-1 to t-5 years. Age can also be an important control variable, as it is related to the Matthew effect (Merton, 1968) and the winner-takes-all society (Frank and Cook, 1995): The more experience and success that one accumulates, the more success that one can then continue to attract. The age of each founder architect was calculated for every year. In addition, we controlled for sex, which may be relevant to reputation in the male-dominated field of French 
architecture. The sex of the founder architects was operationalized by 0 for men and 1 for women.

We also controlled for the interactions between market and expert reputations, between peer and expert reputations, and between peer and market reputations, as there may be crosseffects between the two for each pair.

\section{Data analysis}

We used an unbalanced panel-data set of 42 architecture companies and 1,117 company-year observations, for the sample period 1978-2008. The fact that we built our own database provides us with a longitudinal and richer dataset. We set up a simultaneous equations model (Greene, 2002), based on a system of three structural equations, to study the relationships between peer, market, and expert reputations. Table 1 lists the three structural equations.

The equations contain endogenous variables among the explanatory variables and fixed effects for each company. Furthermore, these endogenous variables are the dependent variables of other equations in the system, meaning that they affect other variables and are, in turn, affected by them. In short, there is a two-way - or simultaneous - relationship between $\mathrm{Y}$ and some of the Xs. It is better to lump together a set of variables that can be determined simultaneously by the remaining set of variables - which is precisely what is done in simultaneous equation models. In these models, there is an equation for each of the mutually/jointly dependent or endogenous variables. And unlike in the single equation 
models, one may not estimate the parameters of a single equation without taking into account information provided by other equations in the system.

The model can be expressed as follows:

$$
\mathrm{Y}_{i t, e}=\alpha_{i, e}+\mathrm{X}_{i t, e} \beta_{e}+\varepsilon_{i t, e}
$$

for $\mathrm{i}=1, \ldots, \mathrm{N}, \mathrm{t}=1, \ldots, \mathrm{T}$ and $\mathrm{e}=1, \ldots, \mathrm{E}$ where $\mathrm{N}, \mathrm{T}$, and $\mathrm{E}$ denote the cross-section of the panel, the time dimension of the panel, and the number of structural equations in the model respectively. $Y_{i t, e}$ is the dependent variable, $\alpha_{i, e}$ represents the company-specific effect, $X_{i t, e}$ is the matrix for the $\mathrm{K}$ explanatory variables (endogenous and exogenous), $\beta_{e}=\left[\beta_{e 1} ; \ldots ; \beta_{e \mathrm{~K}}\right]$ is the vector of structural equation parameters, and $\varepsilon_{\mathrm{it}, \mathrm{e}}$ are the errors $\left(\varepsilon_{\mathrm{it}, \mathrm{e}} \sim \operatorname{IID}\left(0, \sigma_{\varepsilon_{\mathrm{e}}}^{2}\right)\right)$.

As the disturbances are correlated with the endogenous variables, and the error terms among the equations are expected to be interdependent, the ordinary least-squares estimation of the equations is likely to produce biased and inconsistent parameter estimators. To overcome these issues, the three-stage least-squares approach (Greene, 2002) is used to estimate jointly an entire system of structural equations. Three-stage least-squares estimation is a three-step process. Step 1 develops instrumented values for all endogenous variables. These values can be considered as the predicted values resulting from a regression of each endogenous variable on all exogenous variables in the system. Step 2 produces a consistent estimate for the covariance matrix of the equation disturbances. Finally, step 3 performs a generalized leastsquares estimation using the covariance matrix estimated in step 2, and the instrumented values for all endogenous variables, obtained in step 1. Thus, the three-stage least-squares procedure can be shown to produce more efficient parameter estimates, because it takes into account cross-equation correlations. The architecture company's reputation model was estimated with Stata version12. 


\section{FINDINGS}

Descriptive statistics and correlations among the variables are presented in Table 2. The correlation matrix shows that the three forms of reputation are positively correlated with each other, and that there is a positive association between these three kinds of reputation and the age, awards, number of architects, and budget.

----------Insert table 2 here

We used the variance-inflation-factor (VIF) indicator to check for multicollinearity. As all the VIFs are less than the maximum level tolerance (10), we can say that there is no evidence of multicollinearity among the model's explanatory variables. The Appendix provides the details of the multicollinearity tests. Results are supported by satisfactory goodness-of-fit levels of the regressions ( $\mathrm{R}^{2}$ values) and the presence of statistically significant coefficients in the three equations. Table 3 reports the three-stage least-squares estimates for the peer, market, and expert reputation equations.

First, we discuss the results for the hypothesized connections among the three reputations over time. Peer reputation generates positive spillovers on market and expert reputation. The positive spillover over time of peer reputation on market reputation $\left(\beta_{21}=0.446, \mathrm{p}<0.01\right)$ means that the more one is reputed among peers, who expect innovativeness, avant-gardism, and differentiation, the more one will be reputed among clients, who want aesthetic, emblematic buildings to be delivered to the agreed timescale. H1a is confirmed and validates 
the reinforcement of the market opinion of an architecture company based on what peers think. Likewise, there are positive spillover effects of market reputation on peer reputation $\left(\beta_{11}=1.956, \mathrm{p}<0.01\right)$ : The more one is reputed among clients, the more one is reputed among architects. This result contradicts H1b. Regarding the relationships between market and expert reputations, $\mathrm{H} 2 \mathrm{a}$ predicted positive spillover effects of market on expert reputation. Our results suggest that there are spillover effects in this case. Confirming H2a, market reputation negatively spills over on expert reputation over time $\left(\beta_{32}=-3.203, \mathrm{p}<0.01\right)$, suggesting that experts might not value many commercial successes. On the contrary, our results show that expert reputation positively spills over on market reputation over the years $\left(\beta_{22}=-0.455, p<0.01\right)$, confirming H2b. Finally, regarding the interactions between peer and expert reputations, our results confirm that peer reputation positively influences expert reputation, confirming $\mathrm{H} 3 \mathrm{a}\left(\beta_{31}=.490, \mathrm{p}<0.01\right)$. The more an architecture company is reputed among peers, the more that cultural critics value the company. Likewise, the more the critics value a company, the more it is reputed among peers $\left(\beta_{12}=.950, \mathrm{p}<0.01\right)$, confirming H3b.

Second, we discuss the weight of control variables for the three reputations over time. The budget for culture, partly spent on architecture, negatively influences the way the market perceives architecture companies $\left(\beta_{24}=-0.001, \mathrm{p}<0.01\right)$. This suggests that clients may prefer companies other than those in our sample if they have higher budgets. However, the number of architects does not affect peer reputation $\left(\beta_{14}=-0.000, \mathrm{p}=0.24\right)$, and the number of exhibitions does not influence expert reputation $\left(\beta_{34}=0.034, p=0.65\right)$. Awards impact both peer $\left(\beta_{17}=1.703, \mathrm{p}<0.01\right)$ and market $\left(\beta_{27}=-1.053, \mathrm{p}<0.01\right)$ reputations, but not in the same way. Indeed, the more one is rewarded - be it nationally or internationally - the more one becomes reputed among peers, but the less one is valued by clients. This reveals 
that awards may negatively affect invitations to public and prestigious competitions. Age is an important determinant of expert reputation $\left(\beta_{35}=0.306, \mathrm{p}<0.05\right)$. Indeed, the more experienced a founder architect is, the more the relevant company is valued by experts. It is important to put this finding into perspective, with our methodology based on tracking architects' innovative ability over 30 years. Finally, sex has a negative influence on expert reputation $\left(\beta_{36}=-7.505, \mathrm{p}<0.05\right)$, which means that women are less likely to be valued by art and cultural critics over time. It strongly echoes the male-dominated nature of the profession, apparently reinforced by experts.

Finally, all our interaction variables (peer-market, market-expert, and peer-expert) confirm the spillover effects on the three reputations as their associated coefficients are statistically significant $\left(\beta_{13}=-0.03, \mathrm{p}<0.05 ; \beta_{23}=-0.008, \mathrm{p}<0.05 ; \beta_{33}=0.084, \mathrm{p}<0.05\right)$. For instance, the impact of market on peer reputation equals 1.956 when expert reputation equals 0 , but each time expert reputation increases by 1 , the effect of market on peer reputation decreases by 0.03 . This confirms the importance of interactions among the various stakeholders, as the three seem completely interdependent. Figure 1 summarizes these results.

-Insert Figure 1 here

In summary, our model explains more than 70 per cent of peer reputation, 47 per cent of market reputation, and 36 per cent of expert reputation. While this implies that there may be other variables (outside our model) that may impact these reputations and their interactions, it clearly indicates the presence of spillover effects among the various reputations at stake. 
As a consequence, our study suggests several combinations relevant to achieving reputation with peers, clients, and experts. Our study also shows how each type of reputation is influenced by the others, for instance peer reputation is more influenced by market reputation than by expert reputation $\left(\beta_{12}=1.956>\beta_{13}=0.950\right)$; the impacts of peer and expert reputations on market reputation are almost equal $\left(\beta_{21}=0.446 \approx \beta_{23}=0.455\right)$; and expert reputation is positively affected by peer reputation $\left(\beta_{31}=0.490\right)$, while negatively affected by market reputation $\left(\beta_{32}=-3.203\right)$. The model thus helps us to understand the complexity of the reputational issues by highlighting the interactions among the various stakeholders' reputations involved in a selection system.

\section{DISCUSSION}

Our study of the French architecture field explains the linkages among the different reputations that an organization may have among different stakeholders. These reputations may interact with each other both positively and negatively. For example, in our case, while peer reputation reinforces market and expert reputations, market reputation appears to be detrimental to expert reputation. Our findings allow us to advance the literature on the strategic management of reputation in three ways.

First, while extant work explains how companies interact with different stakeholders and build reputations with each of them (Dollinger et al., 1997; Mishina et al., 2012), we complement these studies by showing how different types of reputation generate spillovers over time. This argument resonates with the notion of "reputational commons" (Barnett and Hoffman, 2008), and suggests that spillovers between reputations can occur not just at the industry level but also at the organizational level. In line with the literature on resource spillovers (e.g. Azoulay et al., 2010), and considering that reputation is a key organizational 
resource, it is argued that when two or more stakeholder-specific reputations nourish each other over time there are positive reputational spillovers, and when two or more stakeholderspecific reputations undermine each other over time, there are negative reputational spillovers.

In our analysis of architecture companies, the observed spillovers suggest the pivotal role of peer and market reputations. While peer reputation is apparently a necessary condition to enter and survive in the industry, market reputation seems necessary for initiating a selfreinforcing process. Market reputation among clients is required not only to generate revenues and operate profitably, but also to initiate and sustain positive spillovers with peers that in turn can fuel market reputation. Our analysis shows that peer and market' perceptions of architectural "goods" tend to nourish each other, even if each of them has different criteria and ways of assessing value (e.g. awards). Likewise, peer and expert reputations also positively spill over each other, i.e., nourish each other, over time. However, market and expert reputations seem partly to undermine each other, in that market reputation negatively spills over on expert reputation. When architecture companies become highly reputable among clients, the degree of novelty and avant-gardism tends to decrease, while the experts' role is to identify and promote these criteria of innovativeness.

More broadly, such spillovers can happen in the presence of low reputational "gaps" (Davies et al., 2010), i.e., limited differences of perceptions between multiple stakeholders. Otherwise, stakeholders may not be able to build on each other's reputations, and interactions may not arise. In our case, reputational gaps do not seem to damage (and may even nourish) reputational spillovers, revealing some porosity between peers, clients, and experts. This suggests that companies need to tradeoff between being valued for commercial efficiency and being valued for avant-gardism. This tradeoff echoes a company's "strategic balance" 
(Deephouse, 1999) in responding to different stakeholders' expectations, and highlights how different balances may be needed for addressing different stakeholders. Companies whose strategic balance is more focused on being reputed among peers (being considered as avantgardists) can be seen as "market-makers" (Pontikes, 2012) - i.e., actors who redefine the activity by providing new concepts and visions (such as creating a new genre of architecture e.g., the "environmental perspective," and green or eco-construction). On the contrary, companies whose strategic balance is more focused on being reputed among clients (i.e., markets) can be considered to be "market-takers" (Pontikes, 2012), i.e., they prioritize responding to commercial demands (such as designing a building in the familiar cultural category of "industrial architecture"). In our case, companies seem continually to balance their actions between the three stakeholder profiles over time. When architects become highly valued by the market, they renew their style and signature to be valued by peers and experts. By doing so, and in line with Gemser, Leenders and Wijnberg's (2008) study showing that market and expert evaluations may result in different commercial effects, companies can counterbalance the possibly negative spillovers arising from commercial success. This suggests the need to continually and temporally manage the complexity arising from being able to enhance reputation with one valued stakeholder that may reinforce but also undermine the reputation with another valued stakeholder.

Second, through the specific approach of selection-system theory (e.g., Gemser et al., 2008; Mol and Wijnberg, 2011), we extend prior knowledge on reputational multiplicity and complexity (Barnett and Pollock, 2012; Carter and Deephouse, 1999; Dollinger et al., 1997; Lange et al., 2011; Mishina et al., 2012) by providing insights into the strategic management of reputational spillovers. Specifically, we suggest that managing reputations strategically can be considered to be a two-way reinforcing approach at the organizational and institutional 
levels. At the organizational level, companies need to strategically manage each stakeholderspecific reputation (e.g., Fombrun, 1996; Fombrun and Shanley, 1990; Fombrun et al., 2000; Rindova et al., 2005; 2007). For this purpose, they can draw on communication mechanisms. Indeed, communication facilitates the clarification of expectations and connections between the focal company and each stakeholder profile (Kogut, 2000), reducing the uncertainty through actions (such as stakeholder-specific communication) that can be managed proactively rather than defensively (Combs, Ketchen, Ireland and Webb, 2011). The strategic thrust may therefore lie in the stakeholder-specific promotion and communication to proactively enhance an organization's reputation - a key intangible resource. Even if organizational resources and capabilities at hand are similar (avant-gardism, for instance), a difference of perception can be established through communication strategies tailored to each stakeholder profile. Moreover, in line with Deephouse's study (1999), communication strategies may need to be established in a sequential manner, as the various reputations may not evolve simultaneously. For example, in the case of architecture companies, expert reputation may emerge once the building is finished and can be seen by the wider public, while peer and market reputations can be developed as soon as there are calls to commission a building. As a consequence, organizations that are highly reputed among peers and clients may have to renew and explain their creative journey to experts, who seek to identify and value distinctiveness (Bourdieu, 1983; Baudrillard, 1968). As suggested by Rhee and Valdez (2009), there may be a need to create new positions within companies for managing communication strategies - not at all common for architecture agencies or companies in creative industries more generally.

At the institutional level, companies need to navigate the reputational spillovers among different stakeholders. This appears to be less in the companies' hands, as interactions play 
out among stakeholders themselves. However, these interactions are crucial for companies' institutional strategies, to shape favorably the environment in which they compete for resources (Lawrence, 1999). For instance, as experts echo the positive reputation among peers, the strategic actions directed at peers may indirectly influence experts' perceptions. The pivotal role of peer reputation exemplifies that companies can collaborate and establish strategic alliances with peers and competitors (Dollinger et al., 1997; Stern, Dukerich, and Zajac, 2014; Zuckerman, 2014) - in order to gain more positive attention and evaluation from clients and experts. The resource-based view (e.g. Barney, 1991; Rumelt, 1984), posits that the "value" of both tangible and intangible resources is determined both endogenously and exogenously, i.e., by internal and external stakeholders (Barney, 2001; Lepak, Smith and Taylor, 2007). Our study nuances this idea by arguing that different external stakeholders (such as peers or critics) may value an organizational resource (such as reputation) differently, and that this value is influenced by both collaborative and competitive dynamics (Ansari and Munir, 2008).

Third, while our model was developed in the context of architecture, it offers some broader implications. While we showed the linkages and spillovers among different stakeholderspecific reputations for an organization, the nature and degree of spillovers may depend upon the field under focus. In visual arts, Wijnberg and Gemser (2000) showed how peers, clients, and experts positively influenced each other. Our study of architecture shows that market and experts have a more complex relationship: Experts positively influence clients, but not vice versa. We suggest that this dynamic many hold more generally in professional services such as accounting and law (Cooper et al., 1996; Greenwood, Li, Prakash, and Deephouse, 2005; Jones and Livne-Tarandach, 2008; Von Nordenflycht, 2010), and less so in industries such as music, where peers' assessment is less central. Anyone who aspires to become a musician 
(and has talent - or luck!) could theoretically become one. On the contrary, to practice a profession such as architecture, one needs (although it is a creative profession) a diploma, professional expertise, and the acceptance of self-regulated codes, norms, and ethics.

Professional service companies rely on industry-specific knowledge and expertise, and are tightly regulated by professional and/or peer requirements and apprenticeships. As such, reputational spillovers may have different dynamics depending on the nature of the industry. For instance, our theory development on reputational spillovers may be more relevant for sectors such as design, advertising and academia, but relatively less so for industries such as music, where peers may be less pivotal. As a consequence, the nature and degree of the parameters we developed would need further contextualization.

Our study has several implications for managers. We suggest that a company should not just focus on the stakeholder that it believes to be the most strategic, such as clients, but should instead value a combination of stakeholders. For instance, a company can invest in building relations (and reputation) with peers, and not limit itself just to clients. Indeed, as reputational spillovers come with a cost, it may not be enough for firms to focus on an "overall" reputation. Managers need to be mindful that the company needs to have reputation in various domains, depending on the key stakeholders at stake. Being good for peers may not be the same as being good for clients. However, these stakeholders can build on each other over time to confer peer and market reputations. Companies can communicate more effectively with the market and experts in order to optimize the interactions among them and potentially to increase other reputations over time. As suggested by our two-way reinforcing approach of managing reputation at both the organizational and the institutional levels, managing this balance is complex, as a company may struggle to cope with highly different and at times competing signals from different stakeholders (Spence, 1974). However, by engaging with 
different stakeholders to improve its reputation among them, the company may also benefit from interactions among these stakeholders, which may contribute to improving several stakeholder-specific reputations.

Our study has several limitations. First, by building on selection-system theory, we focused on three types of reputation; peer, market, and expert. Other approaches may provide insights into spillovers among other stakeholder-specific reputations, such as those associated with employees, shareholders, and suppliers; these may need other literatures to be developed or leveraged. Future research may investigate companies' interactions with other kinds of stakeholders, in order to complement and refine our understanding of reputational spillover effects and the conditions of their occurrence. In addition, selectors also develop reputations pertaining to how well their selection systems work and may attempt to "promote" their systems to enhance their reputations. For example, Financial Times competes with other selectors for ranking business schools and their reputations vary. Scholars can examine how the reputations of different evaluating audiences (selectors) may themselves interact and how this may influence the reputations of the organizations they evaluate. Second, our findings may have limited transferability to other domains. It would thus be productive to examine the extent to which our findings hold in other countries and cultural contexts (Kim and Jensen, 2014), other creative sectors (such as design, advertising, and luxury businesses), and other domains of activity (such as academia). Scholars may also consider industries where rating systems exist, such as sports. A third potential limit is our choice not to include electronic media in our data collection. A few newspapers - both those dedicated to architecture and those not - created websites after the 2000s and may have referenced additional articles about our sample of companies. For reasons of longitudinal coherence, we argue that excluding these was the best way to proceed. Future research could investigate companies' electronic 
coverage in the media and perhaps even on social media, in order to highlight the role of electronic media in creating reputations. As electronic sources may be more accessible, it would be useful to examine the types of information sources each stakeholder group uses, as some may rely on more than one main source (Gemser, Van Oostrum and Leenders, 2007). Finally, future studies could examine the relationship between multiple reputations and multiple identities. For instance, managers may promote one or several peripheral attributes of their identity to a particular stakeholder (Gioia, Schultz, and Corley, 2000), but the stakeholder may build on different elements of identity (Deephouse and Jaskiewicz, 2013). Likewise, the notions of influencers and influences from the founders' professional background may be important to understanding the intersection between reputation and identity.

Despite considerable advances in studies on reputation - a key intangible resource for an organization - its complexity calls for further scholarly engagement. By showing that spillovers exist among peer, market, and expert reputations over time in French architecture, we have provided theoretical and empirical insights into the challenges organizations confront in managing different and interacting stakeholder-specific reputations. Our study is an important step toward identifying reputational spillovers, showing how these spillovers might occur, and their implications for studies of the strategic management of reputation. 


\section{BIBLIOGRAPHY}

Alvarez, J.L., Mazza, C., Pedersen Strandgard, and J., Svejenova, S. (2005). “Shielding Idiosyncrasy from Isomorphic Pressures: Towards Optimal Distinctiveness in European Film Making," Organization 12(6): 863-88

Ansari, S. and Munir, K. (2008). "How Valuable is a Piece of the Spectrum? Determination of Value in External Resource Acquisition,” Industrial and Corporate Change 17(2): 301-33

Azoulay, P., Graff Zivin, J.S. and Wang, J. (2010). The Quarterly Journal of Economics: 54989

Barnett, M. L. and Hoffman, A. J. (2008). “Beyond corporate reputation: Managing reputational interdependence," Corporate Reputation Review 11: 1-9

Barnett, M. L. and Pollock, T. G. (2012). The Oxford Handbook of Corporate Reputation. Oxford: Oxford University Press

Barney, J.B. (1991). "Firm Resources and Sustained Competitive Advantage," Journal of Management 17: 99-120

Barney, J.B. (2001). "Resource-based Theories of Competitive Advantage: A Ten-year Retrospective on the Resource-based View," Journal of Management 27: 643-50

Baudrillard, J. (1968). Le Système des Objets : la Consommation des Signes. Paris: Gallimard. 
Becker, H. S. (1982). Arts Worlds. Berkeley: University of California Press

Becker, H. S. (1997). Outsiders. Free Press

Benjamin, B. A. and Podolny, J. M. (1999). "Status, Quality and Social Order in the California Wine Industry,” Administrative Science Quarterly 44: 563-89

Bitektine, A. (2010). "Toward a Theory of Social Judgments of Organizations: The Case of Legitimacy, Reputation and Status," Academy of Management Review 36(1): 151-79

Bowness, A. (1990). The Condition of Success: How the Modern Artists Rise to Fame. Thames and Hudson

Bourdieu, P. (1983). "The Field of Cultural Production, or the Economic World Revised," Poetics 12: 311-56.

Carter, S.M. and Deephouse, D.L. (1999). “'Tough Talk' and 'Soothing Speech’: Managing Reputations for Being Tough and for Being Good," Corporate Reputation Review 2(4)

Caves, R. E. (2000). Creative Industries: Contracts between Art and Commerce. Harvard University Press.

Champy, F. (2001). Sociologie de l'architecture. Paris : La Découverte, Repères 
Combs, J. G., Ketchen, D. J., Ireland, R. D. and Webb, J. W. (2011). “The Role of Resource

Flexibility in Leveraging Strategic Resources,” Journal of Management Studies 48(5): 10981125

Cooper, D.J., Hinings, B., Greenwood, R. and Brown, J.L. (1996). "Sedimentation and transformation in organizational change: The case of Canadian law firms," Organization Studies 17 (4), 623-47

Davies, G., Chun, R. and Kamins, M. A. (2010). "Reputation Gaps and the Performance of Service Organizations," Strategic Management Journal 31(5): 530-46

Deephouse, D.L. (1999). “To Be Different, or to Be the Same? It's a Question (and Theory) of Strategic Balance,” Strategic Management Journal 20(2)

Deephouse, D.L. and Jaskiewicz, P. (2013). "Do Family Firms Have Better Reputations than Non-Family Firms? An Integration of Socioemotional and Social Identity Theory," Journal of Management Studies 50(3): 337-60

Delmestri, G., Montanari, F. and Usai, A. (2005). "Reputation and Strength of Ties in Predicting Commercial Success and Artistic Merit of Independents in the Italian Feature Film Industry," Journal of Management Studies 42(5): 975-1002

Dollinger, M.J., Golden, P.A. and Saxton, T. (1997). “The Effect of Reputation on the Decision to Joint Venture," Strategic Management Journal 18(2): 127-40 
Ebbers, J.J. and Wijnberg, N.M. (2011). “The Effects of Having More than One Good Reputation on Distributor Investments in the Film Industry," Journal of Cultural Economics 36(3): $227-48$

Eikhof, D. and Haunschild, A. (2006). "Lifestyle Meets Market: Bohemian Entrepreneurs in Creative Industries.” Creativity and Innovation Management 15(3): 234-41

Fombrun, C.J. (1996). Reputation: Realizing Value from the Corporate Image. Harvard University Press

Fombrun, C.J., Gardberg, N.A. and Sever, J.M. (2000). “The Reputation Quotient: a MultiStakeholder Measure of Corporate Reputation," The Journal of Brand Management 7(4), p. $241-55$

Fombrun, C.J. and Shanley, M. (1990). "What's in a Name? Reputation Building and Corporate Strategy," Academy of Management Journal 33 (2): 233-58

Fombrun, C.J. and Van Riel, C.B.M. (2003). Fame and Fortune, FT Press

Frank, R. H. and Cook, P. (1995). The Winner-Take-All Society. New York: Penguin Books Galenson, D.W. (2005). “Anticipating Artistic Success,” World Economics 6(2) 
Gemser, G., Leenders, M.A. and Wijnberg, N.M. (2008). "Why Some Awards are more Effective Signals than Others: A Study of Movie Awards," Journal of Management 34(1): $25-54$

Gioia, D. A., Schultz, M. and Corley, K. G. (2000). “Organizational identity, image, and adaptive instability," Academy of Management Review 25(1): 63 - 81

Guillèn, M.F. (1997). “Scientific Management’s Lost Aesthetic: Architecture, Organization, and the Taylorized Beauty of the Mechanical," Administrative Science Quarterly 42(4): 682715

Greene W. (2002). Econometric Analysis. 5th Edition

Greenwood, R., Li, S.X., Prakash, R. and Deephouse, D.L. (2005). "Reputation, Diversification and Organizational Explanations of Performance in Professional Service Firms," Organization Science 16(6): 661-73

Heinich, N. (1991). La Gloire de Van Gogh. Essai d'anthologie de l'admiration. Paris : Editions de Minuit

Heinich, N. (2004). La Sociologie de l'Art. Paris : La Découverte, Repères

Jones, C., Anand, N. and Alvarez, J.L. (2005). "Manufactured Authenticity and Creative Voice in Cultural Industries,” Journal of Management 42(5): 893-99 
Jones, C. and Livne-Tarandach, R. (2008). "Designing a Frame: Rhetorical Strategics of Architects," Journal of Organizational Behavior 29: 1075-99

Jones, C., Maoret, M., Massa, F. and Svejenova, S. (2011). "Rebels with a Cause : Formation, Contestation and Expansion of the De Novo Category 'Modern Architecture', 1870-1975,' Organization Science 23(6): 1523-45

Kim, H. and Jensen, M. (2014). “Audience heterogeneity and the effectiveness of market signals: How to overcome liabilities of foreignness in film exports?" Academy of Management Journal 57 (5): 1360-84.

King, A., Lenox, M. and Barnett, M. (2002). "Strategic responses to the reputation commons problem," in A. Hoffman and M. Ventresca (eds.) Organizations, policy and the natural environment: Institutional and strategic perspectives. Stanford, CA: Stanford University Press, pp 393-406

Kogut, B. (2000). “The Network as Knowledge: Generative Rules and the Emergence of Structure," Strategic Management Journal 21(3): 405-26

Lampel, J. (2000). "Special Issue on Cultural Industries: A Laboratory of Ideas for New Organizational Forms," in Lampel, J., Lant, T. and Shamsie, J. (eds.) Organization Science $11(3)$ 
Lang, G.E. and Lang, K. (1988). "Recognition and Renown: The Survival of Artistic Reputation," American Journal of Sociology 94: 79-109

Lange, D., Lee, P.M. and Dai, Y. (2011). “Organizational Reputation: A Review,” Journal of Management 37(1): 153-84

Lawrence, T. B. (1999). “Institutional Strategy,” Journal of Management 25(2); 161-188.

Love, E. G. and Kraatz, M. (2009). "Character, Conformity or the Bottom Line? How and Why Downsizing Affected Corporate Reputation?" Academy of Management Journal 52(2), $314-35$

Mayer, R.C., Davis, J.H. and Schoorman, F.D. (1995). “An Integrative Model of Organizational Trust," Academy of Management Review 20(3): 709-34

McGuire, J. B., Sundgren, A. and Schneeweis, T. (1988). "Corporate Social Responsibility and Firm Financial Performance," Academy of Management Journal 31: 854-72

Merton, R. K. (1968). “The Matthew Effect in Science.” Science 159: 56-63

Mishina, Y., Block, E.S. and Mannor, M.J. (2012). “The Path Dependence of Organizational Reputation: How Social Judgments Influences Assessments of Capability and Character,” Strategic Management Journal 33: 459-77 
Mol, J.M. and Wijnberg, N.M. (2011). "From Resources to Value and Back: Competition Within and Between Organizations," British Journal of Management 22: 77-95

Moulin, R. (1967). Le Marché de la Peinture en France. Paris : Editions de Minuit

Pfarrer, M. D., Pollock, T. G. and Rindova, V. P. (2010). "A Tale of Two Assets: The Effects of Firm Reputation and Celebrity on Earnings Surprises and Investors' Reactions," Academy of Management Journal 53: 1131-52

Podolny, J.M. (1993). “A Status-Based Model of Market Competition,” American Journal of Sociology 98: 829-72

Pollock, T.G. and Rindova, V.P. (2003). "Media legitimation effects in the market for initial public offerings," Academy of Management Journal 46(5): 631-42

Pontikes, E.G. (2012). “Two Sides of the Same Coin: How Ambiguous Classification Affects Multiple Audiences' Evaluations," Administrative Science Quarterly 57(1) 81-118

Rao, H. (1994). “The Social Construction of Reputation: Certification Contests, Legitimation and the Survival of Organizations in the Automobile Industry: 1895-1912," Strategic Management Journal 15: 29-44

Rao, H., Monin P., Durand R. (2003). "Institutional Change in Toqueville: Nouvelle Cuisine as an Identity Movement in French Gastronomy,” American Journal of Sociology 108(4): 795 $-843$ 
Rhee, M. and Valdez, M. (2009). “Contextual Factors Surrounding Reputation Damage with Potential Implications for Reputation Repair,” Academy of Management Review 34(1):146-68

Rindova, V. P., Petkova, A.P. and Kotha, S. (2007). "Standing Out: How New Firms in Emerging Markets Build Reputation," Strategic Organization 5: 31-70

Rindova, V.P., Williamson, I.O., Petkova, A.P. and Sever, J.M. (2005). "Being Good or Being Known: an Empirical Examination of the Dimensions, Antecedents and Consequences of Organizational Reputation,” Academy of Management Journal 48(6): 1033-49

Rumelt, R. P. (1984). “Towards a Strategic Theory of the Firm,” in R. Lamb (eds.) Competitive Strategic Management. Prentice-Hall, Englewood Cliffs, NJ, pp 556-70

Spence, M. (1974). "Competitive and optimal responses to signals: An analysis of efficiency and distribution," Journal of Economic Theory 7(3): 296-332

Stern, I., Dukerich, J.M. and Zajac, E. (2014). "Unmixed Signals: How Reputation and Status Affect Alliance Formation,” Strategic Management Journal 35: 512-31

Svejenova, S. (2005). “'The Path with the Heart': Creating the Authentic Career," Journal of Management Studies 42(5): 947-74

Svejenova, S., Planellas, M. and Vives, L. (2010). “An Individual Business Model in the Making: a Chef's Quest for Creative Freedom," Long Range Planning 43: 408-30 
Thornton, P. H., Jones, C. an Kury, K. (2005). "Institutional Logics and Institutional Change in Organizations: Transformation in Accounting, Architecture and Publishing," Research in the Sociology of Organizations 23: 125-70

Tost, L. P. (2011). “An Integrative Model of Legitimacy Judgments,” Academy of Management Review 36(4): 686-10.

Von Nordenflycht, A. (2010). "What is a Professional Service Firm? Towards a Theory and Taxonomy of Knowledge Intensive Firms,” Academy of Management Review 35(1): 155-74

White, H.C. and White, C.A. (1965). Canvases and Careers: Institutional Change in the French Painting World. New York, NY: Wiley

Wijnberg, N.M. (2004). "Innovation and Organization: Value and Competition System in Selection System,” Organization Studies 25(8): 1413-33

Wijnberg, N.M. and Gemser, G. (2000). "Adding Value to Innovation: Impressionism and the Transformation of the Selection System in Visual Arts," Organization Science 11(3): 323-29

Winch, G. and Schneider, E. (1993). "Managing the Knowledge-Based Organization: the Case of Architectural Practice," Journal of Management Studies 30(6)

Zucker, L.G., Darby, M.R. and Brewer, M.B. (1998). “Intellectual Human Capital and the Birth of U.S. Biotechnology Enterprises," American Economic Review 88(1): 290-306 
Zuckerman, Ezra W. (2014). "In Either Market or Hierarchy, but Not in Both Simultaneously: Where Strong Ties Are Found in the Economy," Research in the Sociology of Organizations 40: $111-33$

Zuckerman, E.W. (1999). “The Categorical Imperative: Securities Analysts and the Illegitimacy Discount,” American Journal of Sociology 104(5): 1398-1438

\section{AUTHORS BIOGRAPHIES}

Amélie Boutinot is an Assistant Professor at Institut Supérieur de Gestion and Affiliate Professor at Grenoble Ecole de Management. She holds a PhD from University of Grenoble. Her research interests are dedicated to recognition and social approval processes in professional service firms and creative industries. She is also interested in the macro context influencing these processes, for instance through institutional logics and creative genres. She has published in international academic journals such as Journal of Business Research, European Management Journal and M@n@gement.

Dr Shaz Ansari is a Reader (Associate Professor) at Judge Business School, University of Cambridge and Visiting Faculty at Rotterdam School of Management, Erasmus University. He holds a PhD from University of Cambridge. He serves or has served on the Editorial Boards of Academy of Management Review, Organization Science, Journal of Management Studies and Organization Studies, and is a member of Erasmus Research Institute of Management (ERIM). His research interests include institutional processes and diffusion of practices; social movements, social and environmental issues in management, technological and management innovations; value creation, new markets; reputation management, and bottom-of-the-pyramid strategies. He has published in several leading academic journals 
including Academy of Management Journal, Academy of Management Review, Organization Science, Journal of Management Studies, Research Policy, Industrial and Corporate Change, Strategic Organization, and Organization Studies.

Mustapha BELKHOUJA is an Assistant Professor of quantitative methods in the department of Management Technology and Strategy at Grenoble Ecole de Management. He holds his Ph. D. in Econometrics from Université de la Méditerranée Aix-Marseille 2 (2010). His work has appeared in Computational Economics and Economic Modelling. His current research topics include academic visibility, reputation management, entrepreneurship and international business.

Vincent Mangematin is Professor of strategic Management and scientific director at Grenoble Ecole de Management (France). His research stands at the intersection of Strategic Management and Innovation. He focuses on emergent phenomenon and on the transformative influence of digital technologies in the society. In the recent years, he has been focusing on business models as an approach to renew strategy. He is recognised as a stimulating scholar on topics related to innovation and emergence. He is associate editor in Technovation and M@n@gement. He is serving in the Editorial board of Organization Studies, Research Policy and Technological Forecasting and Social. 


\section{TABLES}

Peer reputation equation Market reputation equation Expert reputation equation

\begin{tabular}{lll}
\hline Market reputation* & Peer reputation* & Peer reputation* \\
Expert reputation* & Expert reputation* & Market reputation* \\
Market x expert & Peer x expert & Peer x market \\
Number of architects & Budget (in million $€$ ) & Exhibitions \\
Sex & Sex & Sex \\
Age & Age & Age \\
Awards & Awards & Awards \\
Architect indicator & Architect indicator & Architect indicator \\
\hline
\end{tabular}

* Endogenous variables

Table 1. Simultaneous equations model 


\begin{tabular}{|c|c|c|c|c|c|c|c|c|c|c|c|c|c|}
\hline Variables & Mean & S.D. & Min & Max & 1 & 2 & 3 & 4 & 5 & 6 & 7 & 8 & 9 \\
\hline $\begin{array}{l}\text { 1.Peer } \\
\text { reputation }\end{array}$ & 11.55223 & 14.50177 & 0 & 92 & 1.0000 & & & & & & & & \\
\hline $\begin{array}{l}\text { 2.Market } \\
\text { reputation }\end{array}$ & 4.522273 & 5.140221 & 0 & 41 & $0.3178^{*}$ & 1.0000 & & & & & & & \\
\hline $\begin{array}{l}\text { 3.Expert } \\
\text { reputation }\end{array}$ & 5.162826 & 15.06332 & 0 & 267 & $0.6548 *$ & $0.2321^{*}$ & 1.0000 & & & & & & \\
\hline 4.Age & - & - & 23 & 76 & $0.4507 *$ & $0.471^{*}$ & $0.2922 *$ & 1.0000 & & & & & \\
\hline 5.Sex & - & - & 0 & 1 & $-0.1064 *$ & $-0.1684^{*}$ & -0.0648 & $-0.2432 *$ & 1.0000 & & & & \\
\hline 6.Awards & .2501967 & .6073289 & 0 & 4 & $0.3452 *$ & 0.0209 & $0.2793 *$ & 0.0540 & -0.0263 & 1.0000 & & & \\
\hline $\begin{array}{l}\text { 7.Number } \\
\text { of } \\
\text { architects }\end{array}$ & 30758.06 & 7822.409 & 14500 & 39500 & $0.5047^{*}$ & $0.4502^{*}$ & $0.2859 *$ & $0.7452^{*}$ & 0.0000 & $0.0911^{*}$ & 1.0000 & & \\
\hline $\begin{array}{l}\text { 8.Budget } \\
\text { (in million } \\
\text { €) }\end{array}$ & 1500 & 788.3179 & 250 & 2500 & $0.5044 *$ & $0.4587^{*}$ & $0.2974 *$ & $0.7618^{*}$ & -0.0000 & $0.1081^{*}$ & $0.8965 *$ & 1.0000 & \\
\hline $\begin{array}{l}\text { 9.Exhibi } \\
\text { tions }\end{array}$ & 2.214286 & 4.92427 & 0 & 38 & 0.0292 & -0.0482 & 0.0298 & -0.0187 & $0.2182 *$ & 0.0385 & -0.0144 & -0.0054 & 1.0000 \\
\hline
\end{tabular}

$* p<.1 ; * * p<.05 ; * * * p<.01$

Table 2. Descriptive statistics and correlation matrix 


\begin{tabular}{|c|c|c|c|c|c|c|c|c|c|}
\hline & \multicolumn{2}{|c|}{$\begin{array}{l}\text { Peer-reputation } \\
\text { equation }\end{array}$} & & \multicolumn{2}{|c|}{$\begin{array}{l}\text { Market-reputation } \\
\text { equation }\end{array}$} & \multicolumn{3}{|c|}{$\begin{array}{l}\text { Expert-reputation } \\
\text { equation }\end{array}$} & \multirow[b]{2}{*}{ p-value } \\
\hline & Coeff. & t-stat & p-value & Coeff. & t-stat & p-value & Coeff. & t-stat & \\
\hline Peer reputation* & - & - & - & 0.446 & 17.66 & 0.000 & 0.490 & 4.00 & 0.000 \\
\hline Market reputation* & 1.956 & 12.56 & 0.000 & - & - & - & --3.203 & -7.02 & 0.000 \\
\hline Expert reputation* & 0.950 & 18.36 & 0.000 & 0.455 & 8.66 & 0.000 & - & - & - \\
\hline Market $x$ expert & --0.03 & -7.06 & 0.000 & - & - & - & - & - & - \\
\hline Number of architects & 0.000 & 1.16 & 0.247 & - & - & - & - & - & - \\
\hline Peer $x$ expert & - & - & - & --0.008 & -12.11 & 0.000 & - & - & - \\
\hline Budget (in million $€$ ) & - & - & - & --0.001 & -4.31 & 0.000 & - & - & - \\
\hline Peer x market & - & - & - & - & - & - & 0.084 & 5.38 & 0.000 \\
\hline Exhibitions & - & - & - & - & - & - & 0.034 & --0.45 & 0.655 \\
\hline Age & --0.101 & --1.46 & 0.144 & 0.005 & 0.21 & 0.835 & 0.306 & 3.31 & 0.001 \\
\hline Sex & 1.689 & 0.68 & 0.498 & --1.367 & --1.23 & 0.219 & --7.505 & --2.06 & 0.040 \\
\hline Awards & 1.703 & 2.82 & 0.005 & --1.053 & --3.71 & 0.000 & --1.250 & --1.60 & 0.110 \\
\hline $\mathbf{R}^{2}$ & & 0.7093 & & & 0.4710 & & & 0.3644 & \\
\hline
\end{tabular}

\section{* Endogenous variables}

Note: Significant coefficients are in bold.

Table 3. Simultaneous equations model results 


\section{FIGURES}

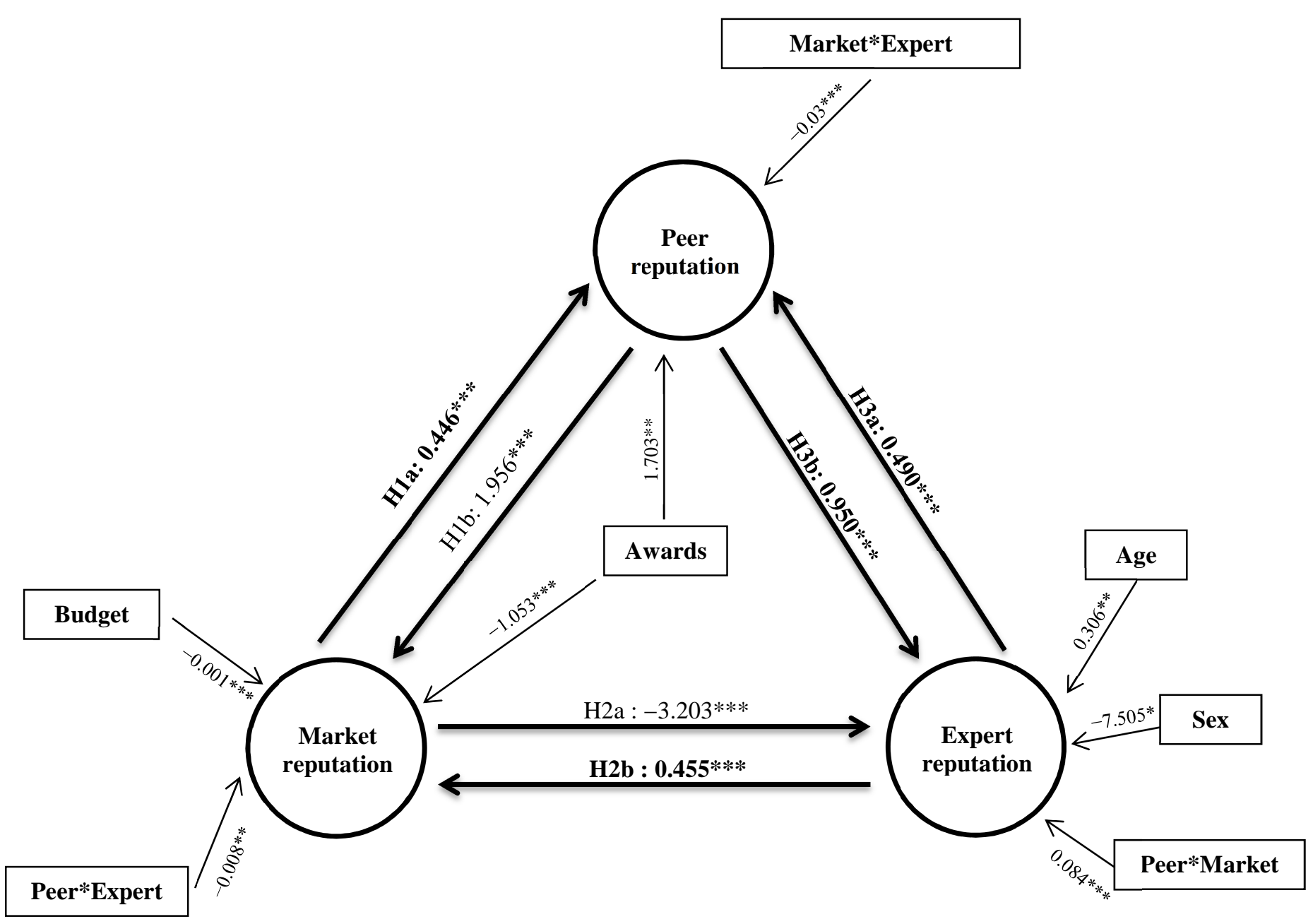

- $\quad * p<.05 ; * * p<.01 ; * * * p<.001$

- $\quad$ The validated hypotheses are in bold.

Figure 1. Simultaneous equations model results 
Reputational Spillovers

APPENDIX

\begin{tabular}{|c|c|c|c|c|c|c|c|c|c|c|c|c|}
\hline & $\begin{array}{l}\text { Peer rept } \\
\text { equation }\end{array}$ & ation & & & $\begin{array}{l}\text { Market } r \\
\text { equation }\end{array}$ & putation & & & $\begin{array}{l}\text { Expert reputation } \\
\text { equation }\end{array}$ & & & \\
\hline & Coeff. & t-stat & $\mathrm{p}$-value & VIF & Coeff. & $\mathrm{t}$-stat & p-value & VIF & Coeff. & t-stat & p-value & VIF \\
\hline $\begin{array}{l}\text { Peer } \\
\text { reputation }\end{array}$ & - & - & - & - & 0.02 & 2.29 & 0.022 & 2.34 & 0.41 & 9.96 & 0.000 & 3.70 \\
\hline $\begin{array}{l}\text { Market } \\
\text { reputation }\end{array}$ & 0.35 & 4.87 & 0.000 & 1.99 & - & - & - & - & -0.58 & -5.02 & 0.000 & 3.68 \\
\hline $\begin{array}{l}\text { Expert } \\
\text { reputation }\end{array}$ & 0.63 & 20.20 & 0.000 & 3.31 & 0.14 & 5.64 & 0.000 & 9.91 & - & - & - & - \\
\hline $\begin{array}{l}\text { Market_ } \\
\text { expert }\end{array}$ & -0.01 & -6.32 & 0.000 & 3.73 & - & - & - & - & - & - & - & - \\
\hline $\begin{array}{l}\text { Peer_ } \\
\text { expert }\end{array}$ & - & - & - & - & -0.001 & -5.22 & 0.000 & 9.12 & - & - & - & - \\
\hline $\begin{array}{l}\text { Peer_ } \\
\text { market }\end{array}$ & - & - & - & - & - & - & - & - & 0.03 & 7.56 & 0.000 & 5.76 \\
\hline Age & 0.02 & 0.51 & 0.609 & 2.79 & 0.08 & 4.47 & 0.000 & 2.90 & 0.10 & 2.69 & 0.007 & 1.85 \\
\hline Sex & -2.42 & -2.50 & 0.013 & 1.19 & -1.87 & -4.11 & 0.000 & - & 0.17 & 0.15 & 0.879 & 1.12 \\
\hline Awards & 3.03 & 8.63 & 0.000 & 1.10 & -0.56 & -2.57 & 0.010 & 1.16 & 1.73 & 3.11 & 0.002 & 1.16 \\
\hline $\begin{array}{l}\text { Number of } \\
\text { architects }\end{array}$ & 0.00 & 9.51 & 0.000 & 2.62 & - & - & - & - & - & - & - & - \\
\hline Budget & - & - & - & - & 0.001 & 5.24 & 0.000 & 2.98 & - & - & - & - \\
\hline $\begin{array}{l}\text { Exhibi } \\
\text { tions }\end{array}$ & - & - & - & - & - & - & - & - & 0.05 & 0.84 & 0.402 & 1.06 \\
\hline Constant & -10.23 & -7.82 & 0.000 & - & -1.94 & -2.95 & 0.003 & - & -3.31 & & 0.001 & - \\
\hline
\end{tabular}

Appendix. Multicollinearity test 